\title{
Supplementary Foliar Applications and Their Effect on the Agronomic Behavior of Strawberry in a Vertical System
}

\author{
María del Pilar Marín Cortez ${ }^{1}$, Antonio Flores Naveda ${ }^{2}$, \\ Perpetuo Álvarez Vázquez ${ }^{3}$, Josué Israel García López ${ }^{2}$, \\ Armando Robledo Olivo ${ }^{4}$, Xohitl Ruelas Chacon ${ }^{4}$ \\ and Neymar Camposeco Montejo ${ }^{\star}$
}

${ }^{1}$ Division of Biological and Enviromental Healt Sciences, Universidad Abierta y a Distancia de México, Avenida Universidad 1200, Xoco, Alcaldia Benito Juarez, Ciudad de México, CP, 03330, México.

${ }^{2}$ Seed Technology Training and Development Center, Departament of Plant Breeding, Universidad Autónoma Agraria Antonio Narro, Calzada Antonio Narro 1923, Buenavista, Saltillo CP, 25315,

Coahuila, México.

${ }^{3}$ Departament of Natural Resource, Universidad Autónoma Agraria Antonio Narro, Calzada Antonio Narro 1923, Buenavista, Saltillo CP, 25315, Coahuila, México. ${ }^{4}$ Departament of Science and Food Tecnology, Universidad Autónoma Agraria Antonio Narro, Calzada Antonio Narro 1923, Buenavista, Saltillo CP, 25315, Coahuila, México.

Authors' contributions

This work was carried out in collaboration among all authors. Authors NCM, MPMC, AFN and PÁV designed the study, performed the statistical analysis, wrote the protocol and wrote the first draft of the manuscript. Authors NCM, JIGL, AFN and ARO managed the analyzes of the study and helped in the interpretation of results. Authors MPMC and XRC managed the literature searches. All authors read and approved the final manuscript.

Article Information

DOI: 10.9734/ARRB/2021/v36i230346 Editor(s):

(1) Dr. David E. Martin, Martin Pharma Consulting, LLC Shawnee And Director and Founder DFH Pharma Inc., Gaithersburg, Maryland. Reviewers:

(1) Wisam Khazaal Khalid, university of Mosul, Iraq (2) Giovanni Mian, University of Udine, Italy. Complete Peer review History: http://www.sdiarticle4.com/review-history/66517

Original Research Article

Received 14 January 2021

Accepted 23 March 2021

Published 30 March 2021

ABSTRACT

Aims: The objective was to evaluate the agronomic behavior of the strawberry crop under supplementary foliar applications in a vertical system.

*Corresponding author: E-mail: neym_33k@hotmail.com; 
Study Design: The experimental design used in each test was the completely randomized experimental model with six treatments and four repetitions each. The treatments were Control, Estimulante plus $®$, AeroBiot $\circledast$, BasfoliarAktiv $®$, Basfoliar PS $®$ and HPLS.

Place and Duration of Study: The research was carried out under a greenhouse in Saltillo, Coahuila, Mexico. From October 20, 2019 to February 20, 2020.

Methodology: The San Andreas strawberry variety was used, the vertical system consisted of 4" PVC tubes, $1.2 \mathrm{~m}$ long, with $5 \mathrm{~cm}$ diameter perforations, a mixture of peat moss and perlite was used as substrate in a ratio 70:30 \%. The foliar applications were carried out every week, stimulant plus $₫$, AeroBiot $\circledast$, Basfoliar Activ $®$ and HPLS were at a rate of $2 \mathrm{ml} \mathrm{L}^{-1}$, Basfoliar PS® was at a rate of $2 \mathrm{~g} \mathrm{L-}{ }^{1}$, the control was only distilled water.

Results: The foliar application of AeroBiot $₫$ statistically improved the average weight of the fruit and exceeded the control by $16.7 \%$, the length of the fruit was statistically similar between the applications of BasfoliarActiv $®$, AeroBiot $®$, Basfoliar PS $®$ and HPLS, the rest of the variables showed a similar statistical behavior.

Conclusion: The agronomic performance of strawberry cultivation in a vertical system was similar between supplementary foliar applications of products containing macro and microelements, amino

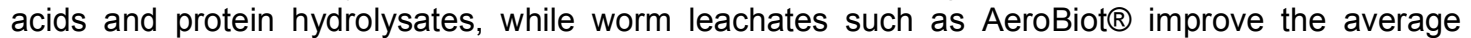
weight of the fruit.

Keywords: Aminoacids; protein hydrolysates; vertical system; Fragaria sp.

\section{INTRODUCTION}

In the last 25 years, strawberry exports in the world increased by $119.7 \%$, with an export volume of more than $865,000 \mathrm{t}$ in 2018 , currently, strawberry cultivation is becoming increasingly important in Mexico, from 2010 to 2014 the increase in the cultivated area was $52 \%$, while from 2014 to 2018 it was $37.5 \%$, with an average annual growth of $7.5 \%$ in the last five years. The cultivated area in 2019 was 13,710 hectares, with a production of 653,639 tons and a production value of 13, 401 million pesos, the states that lead by production are Michoacán (72.4\%), Baja California (14\%) and Guanajuato (9\%) [1]. Strawberry exports represent $52 \%$ of the total produced and the main export market is the US [2], with a value of 6,968 million pesos [1].

On the other hand, the roots are the main sink through which the plants take the nutrients, however, the plants can also be nourished through the leaves, and it is generally through mineral salts dissolved in water [3], that is why, in the agricultural products market, those destined for foliar applications abound, and these can be products with mineral content of macro and micronutrients, amino acids, hormones, mixtures of them [4], content of sugars or sucrose [5,6], which enter the leaves through the cuticle, stomata, ectodesmata, hydathodes [7], trichomes or lenticels [8]. Therefore, foliar nutrition has always been used to make supplements or amendments to crops, since there are reports since 1884, sometimes, nutritional programs include programmed foliar applications, in order to avoid the minimum nutritional deficiencies in the plant [9] or reduce periods of abiotic or biotic stress by applying stimulants $[10,11,12]$, and it is a practice that is increasingly used by producers.

Research focused on discovering the benefits of foliar products on crops, as the results described are diverse and highly variable [13]. In foliar applications in strawberry cultivation, for example, the use of $1 \%$ urea and sucrose [14], selenite [15], hormonal such as 6BAP have been reported, AG3, AG4 + AG7 [11] and macroelements such as calcium [16]. On the other hand, it has been documented that the cultivation of strawberries in a vertical system produces higher yields and therefore higher profitability [17], and that the use of vertical and horizontal space can triple the yields per unit of surface [18]. Therefore, due to the potential benefits that the various products for foliar applications could cause to the strawberry crop, together with the imminent productive potential that the crop represents in a vertical system, it was then proposed to evaluate the agronomic behavior of the strawberry crop under supplemental foliar applications in a vertical growing system.

\section{MATERIALS AND METHODS}

\subsection{Description of the Experimental Site}

The study was carried out from October 20, 2019 to February 20, 2020, in a medium-technology 
greenhouse at the Antonio Narro Autonomous Agrarian University, Saltillo, Coahuila, Mexico. Located at $25^{\circ} 21^{\prime \prime} 24^{\prime \prime} \mathrm{N}$ and $101^{\circ} 02^{\prime} 05^{\prime \prime} \mathrm{W}$, at an altitude of 1762 meters above sea level, with an average annual rainfall of $400 \mathrm{~mm}$ and an average annual temperature of $12-18^{\circ} \mathrm{C}$.

\subsection{Genetic Material}

To carry out the experiment, the San Andreas strawberry variety was used, which is described as a moderate day neutral variety, of excellent fruit quality, of excellent flavor, with little need for cold in winter. With resistance to diseases such as phytophthora, collecotrichum, botrytis and oidio.

\subsection{Preparation of the Vertical Cultivation System}

The vertical system consisted of six 4" PVC tubes each $1.2 \mathrm{~m}$ long, with holes of approximately $5 \mathrm{~cm}$ in diameter, the distance between holes was $20 \mathrm{~cm}$ and between rows of holes $8.75 \mathrm{~cm}$ approximately in a triangular or staggered arrangement (Fig. 1-A, B, C and D). The interconnected tubes for the drainage of the
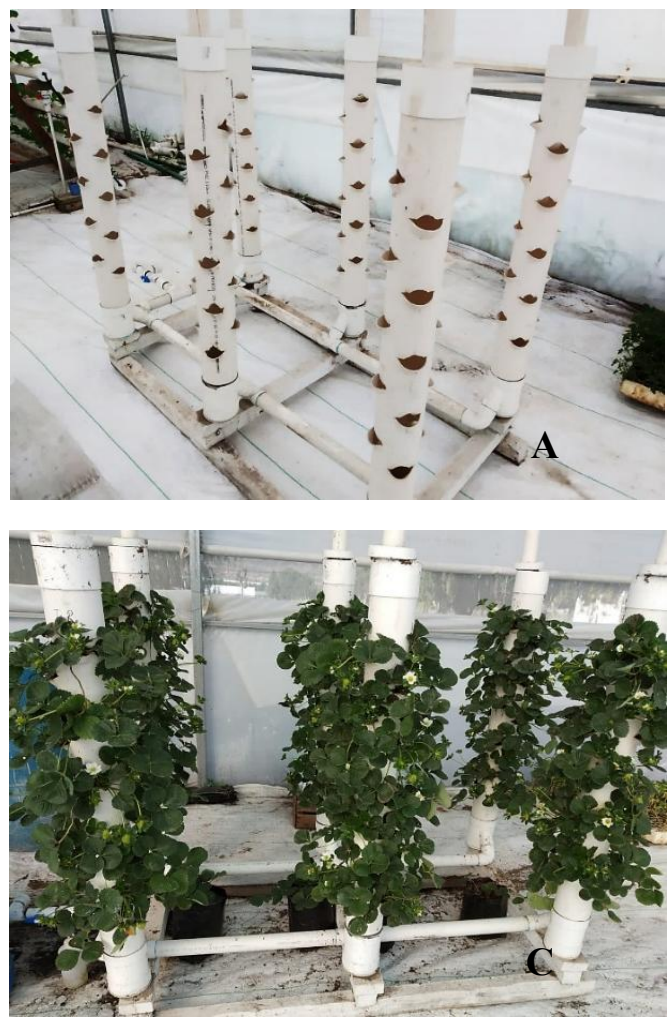

nutrient solution and prostrated on a $20 \mathrm{~cm}$ high wooden base that allowed the drained nutrient solution to be collected, the PVC tubes were filled with a substrate mixture that was peat moss and perlite in a proportion 70:30 \% respectively before transplantation of strawberry.

\subsection{Establishment of Cultivation in Vertical System}

The strawberry plants used were obtained from stolons of mother plants, stolons that were cut and placed in 200 cavity polystyrene trays with a mixture of peat moss and perlite substrate in a 70:30 \% proportion respectively. For its rooting, the commercial product Rooting ${ }^{\circledR}$ was used at a rate of $1 \mathrm{ml} \mathrm{L}^{-1}$, which was applied once a week and for three consecutive weeks. When the plants were 21 days old in a tray for rooting and growth, they were transplanted the vertical system, which was made by placing a mold identical to the cavity of the tray in the perforation and inside the substrate that contained the vertical system, once made. Drilling the plants were removed from the tray and transplanted to the vertical system for the execution of the investigation.

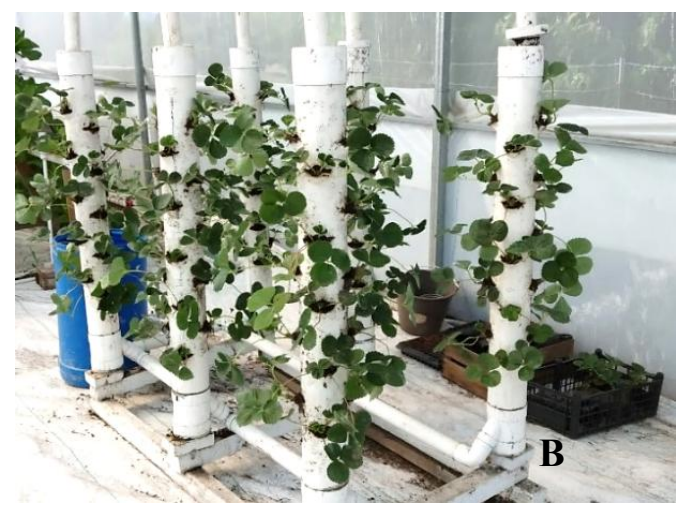

Fig. 1. Prepared vertical system (A), with three-week transplant strawberry plants (B). strawberry plants in full fruiting (C), strawberry plants in maturity and harvest (D) 
Table 1. Nutrient content of foliar treatments applied as a supplement to strawberry cultivation in a vertical system

\begin{tabular}{|c|c|c|c|c|c|c|}
\hline Product content & Control & $\begin{array}{l}\text { Estimulante } \\
\text { Plus } ₫\end{array}$ & AeroBiot ${ }^{\circledR}$ & $\begin{array}{l}\text { Basfoliar } \\
\text { Activ } \AA\end{array}$ & $\begin{array}{l}\text { Basfoliar } \\
\text { PS } ®\end{array}$ & HPLS \\
\hline $\mathrm{N}$ total & - & $8 \%$ & $0.0061 \%$ & $3 \%$ & $25 \%$ & - \\
\hline $\mathrm{P}\left(\mathrm{P}_{2} \mathrm{O}_{5}\right)$ & - & - & $0.000037 \%$ & $27 \%$ & $10 \%$ & - \\
\hline $\mathrm{K}\left(\mathrm{K}_{2} \mathrm{O}\right)$ & - & - & $0.051 \%$ & $18 \%$ & $17 \%$ & - \\
\hline Boron & - & - & $0.007 \%$ & $0.01 \%$ & $0.01 \%$ & - \\
\hline Molybdenum & - & - & - & $0.001 \%$ & $0.001 \%$ & - \\
\hline Copper & - & - & - & $0.02 \%$ & $0.02 \%$ & - \\
\hline Iron & - & - & - & $0.02 \%$ & $0.05 \%$ & - \\
\hline Zinc & - & - & $0.01 \%$ & $0.01 \%$ & $0.02 \%$ & - \\
\hline Manganese & - & - & $0.01 \%$ & $0.01 \%$ & $0.05 \%$ & - \\
\hline Magnesium & - & - & $0.55 \%$ & - & $0.60 \%$ & - \\
\hline Sulfur & - & - & $0.16 \%$ & - & $2.28 \%$ & - \\
\hline Calcium & - & - & $2.66 \%$ & - & - & - \\
\hline Sodium & - & - & $0.01 \%$ & - & - & - \\
\hline Chlorine & - & - & $0.02 \%$ & - & - & - \\
\hline Ammonium & - & - & $0.16 \%$ & - & - & - \\
\hline Microorganisms & - & - & $0.04 \%$ & - & - & - \\
\hline Aminoacids & - & $24 \%$ & - & - & - & - \\
\hline Protein hydrolysate & - & - & - & - & - & $11 \%$ \\
\hline
\end{tabular}

Table 2. Chemical nutritional composition of the nutritive solution (NS) used in irrigation for the production of strawberries in a vertical system

\begin{tabular}{|c|c|c|c|c|c|c|c|}
\hline & \multicolumn{7}{|c|}{ Macroelements } \\
\hline NS & $\mathrm{NO}_{3}^{-}$ & $\mathrm{H}_{2} \mathrm{PO}_{4}^{-}$ & $\mathrm{SO}_{4}{ }^{2-}$ & $\mathrm{HCO}_{3}^{-}$y $\mathrm{CO}_{3}{ }^{2}$ & $\mathbf{K}^{+}$ & $\mathrm{Mg}^{2+}$ & $\mathrm{Ca}^{2+}$ \\
\hline$(\%)$ & \multicolumn{7}{|c|}{ Miliequivalents $\mathrm{L}^{-1}$} \\
\hline 100 & 7 & 1 & 6 & 1 & 5 & 3 & 6 \\
\hline 75 & 4.88 & 0.75 & 4.5 & 1 & 3.75 & 2.25 & 4.5 \\
\hline & \multicolumn{7}{|c|}{ Microelements } \\
\hline SN & $\mathrm{Fe}^{3+}$ & $\mathrm{Mn}^{2+}$ & $\mathrm{H}_{3} \mathrm{BO}_{3}$ & $\mathrm{Zn}^{2+}$ & $\mathrm{Cu}^{+}$ & MoO & \\
\hline$(\%)$ & \multicolumn{7}{|c|}{ Parts per million (ppm) } \\
\hline 100 & 3 & 1.48 & 0.28 & 0.24 & 0.12 & 0.08 & \\
\hline 75 & 2.25 & 1.11 & 0.21 & 0.18 & 0.09 & 0.06 & \\
\hline
\end{tabular}

A completely randomized experimental arrangement was used with six supplementary foliar treatments that were; the Control, Stimulant plus $®$ from MANVERT, AeroBiot $\circledR$ (Worm Leachate) from FERTILOM, BasfoliarAktiv $®$ and Basfoliar PS® from COMPO EXPERT, HPLS (experimental milk whey protein hydrolysate) (Table 1) and four repetitions each, where each PVC tube with 20 plants represents a treatment and a total of five plants for each repetition, the foliar applications were made every week and distilled water was used for its application, for stimulant plus $®$, AeroBiot $\circledast$, Basfoliar Activ $®$ and HPLS were at a rate of $2 \mathrm{ml} \mathrm{L}^{-1}$, while Basfoliar $P S \circledR$ was at a rate of $2 \mathrm{~g} \mathrm{~L}^{-1}$. The control was only distilled water.

The composition of the nutritive solutions used as a base to nourish the plants via the roots are shown in Table 2. The $\mathrm{CO}_{3}^{-}$and $\mathrm{HCO}_{3}^{-}$were neutralized with phosphoric and nitric acid in such a way that in the irrigation water they contributed $1 \mathrm{mEq} \mathrm{L}-1$ of $\mathrm{HCO}_{3}^{-}$which represents the alkalinity of the water with $6.2 \mathrm{pH}$, the nutrient solution was supplied as a percentage in two stages of growth of the crop, $75 \%$ five after transplantation, once flowering started, $100 \%$ was supplied (Table 2), the which was maintained until the end of the experiment, $10 \%$ drainage was used. For the control of red spider (Tetranichus urticae) weekly applications of abamectin 1.8\%, deltamethrin $1.01 \%+$ Imidacloprid $7.6 \%$ were made at a rate of $1 \mathrm{ml} \mathrm{L}^{-1}$.

\subsection{Determination of Evaluated Variables}

To determine the yield variables, six harvests were carried out at weekly intervals, the first was on January 10, 2020 and the last on February 14, 2020. The yield in grams per plant was 
estimated by harvesting all the ripe fruits (more than $50 \%$ red coloration) of each plant, in each harvest, which were weighed on a precision digital scale SARTORIUS model TS 1352Q37, the number of fruits that were harvested from each plant, the average fruit weight was also counted It was calculated dividing the total weight of fruits harvested by the total number of fruits per plant, while the equatorial diameter of the fruit (EDF) and length of the fruit was estimated at five fruits for each repetition and in each harvest carried out and a digital vernier was used Autotec $\circledast$ brand. Leaflet length (LL), leaflet width (LW) was quantified in five leaflets of each repetition, length of fruit bunch (LFB) and leaf petiole length (LPL), were determined in five leaflets for each repetition and it was measured with a measuring tape graduated in $\mathrm{cm}$, to quantify the fresh and dry weight of leaves (FWL and DWL) the same precision balance was used with which yield was determined.

\subsection{Determination of Fruit Quality}

Total soluble solids were determined with an Atago $\circledast$ brand digital refractometer and the data obtained in degrees brix was recorded. The firmness of the fruit was quantified with a Fruit Presure Tester penetrometer, model FT-327 of $13 \mathrm{~kg}$, with a $3 \mathrm{~mm}$ tip. For both variables, the same fruits were used, whose length and equatorial diameter were quantified.

\subsection{Statistic Analysis}

Statistical analysis was performed with the SAS version 9.1 program. The experimental model was completely randomized with six treatments and four repetitions each and significance of $P=.05$, with comparison of LSD Fisher means $(L S D \leq .05)$.

\section{RESULTS AND DISCUSSION}

\subsection{Agronomic Performance Indicators}

According to the ANOVA $(P=.05)$ performed and the $L S D \leq .05$ mean test performed, no statistical significance was detected between applied foliar treatments (Table 3), in the response variables of equatorial diameter of fruit (EDF), length of leaflet (LL), leaflet width (LW), fresh weight of leaves (FWL), dry weight of leaves (DWL) and length of fruit bunch (LFB), so it is inferred that supplementary foliar applications with Products of different origin and content do not necessarily generate positive effects on these variables, as long as root nutrition is adequately provided [19], since the nutritional status of the plant is determined by absorption of nutrients, which determines the assimilation of these nutrients [8]. While in the variable of leaf petiole length (LPL) the foliar applications with AeroBiot $\AA$, BasfoliarAktiv $\AA$, HPLS and Control had a similar statistical behavior, with the exception of Basfoliar PS ${ }^{\circledR}$ and stimulant plus $\circledast$ that presented lower results than before cited.

\subsection{Yield and Yield Components}

The foliar application of the AeroBiot $\AA$ product, which is a product derived from earthworm leachate, statistically improved the average weight of the fruit with $17.11 \mathrm{~g}$ (Fig. 2), higher than the control by $16.7 \%$, which was probably due to, to the proportion of some macroelements, microelements and the ammonium that it contributed, since due to its content, the worm leachates increase the production of photoassimilates [20], which translates into an increase in yield and some of its components, and in high doses (30 ml.L-1) the best results are observed [21], in addition, earthworm leachates represent a sustainable alternative to increase quality and yields [22], since it can be used as a growth promoter [23], the rest of the treatments showed a similar statistical performance. Meanwhile, in the fruit length variable, a similar statistical behavior was observed between the foliar applications of BasfoliarActiv $\AA$, AeroBiot $₫$, Basfoliar PS $®$ and HPLS with 42.24, 41.09, 39.71 and $39.47 \mathrm{~mm}$ respectively, which could be explained due to the supply of macro and micronutrients provided by said products and the free amino acids and peptides provided by HPLS, while the Control and Stimulant plus $₫$ were lower than those mentioned above. The amino acid content of Estimulante plus $₫$ probably did not reflect a good performance of the crop, since apparently the plants did not suffer any type of stress, since amino acids are generally used to counteract the effect of biotic and abiotic stress [24,10,25].

In the yield variable ( $\mathrm{g}$ plant $\left.^{-1}\right)$, no statistical significance was found between applied foliar treatments (Fig. 3), similar results were found when applying selenite [15], 1\% urea and sucrose [14], however, the treatment that was percentage superior to the others, was HPLS with $391.5 \mathrm{~g}$ per harvested plant, and exceeded the Control in $15.7 \%$, similar effects could be observed in number of fruits per plant, since HPLS exceeded the Control by $17.3 \%$, which could be explained in that said product contains mainly free amino acids and soluble peptides, which are immediately incorporated into 
enzymatic reactions that activate the synthesis of phytohormones or as a direct nutrient $[26,12]$, they are also easily absorbed and assimilated both via foliar and root and are quickly transported to the organs of greatest demand [27], where rapidly incorporate into cellular metabolism, saving energy for plants [12], improving crop yield and quality [28]. Basfoliar $\mathrm{PS} \otimes$ and Basfoliar Activ $\AA$ products also showed slight percentage increases in both variables.

\subsection{Fruit Quality}

In the fruit quality variables such as firmness and total soluble solids, statistical significance was not found between applied foliar treatments (Fig. 4), which indicates that the composition of the applied foliar products did not influence the significant modification of these variables of quality, so its use could be omitted if the objective is to improve these variables. The results of total soluble solids agree with the values reported in strawberries treated with selenium [15] and in strawberries treated with gibberellins and cytokinins [11]. For its part, the firmness of the fruit also corresponds to those discovered by [11], while foliar applications of calcium help to improve this fruit quality variable [16].

Table 3. Analysis of variance and LSD Fisher test of means $(L S D \leq .05)$ of agronomic variables of strawberry treated with different supplementary foliar products

\begin{tabular}{llllllll}
\hline Treatments & $\begin{array}{l}\text { EDF } \\
(\mathbf{m m})\end{array}$ & $\begin{array}{l}\text { LL } \\
(\mathbf{c m})\end{array}$ & $\begin{array}{l}\text { LW } \\
(\mathbf{c m})\end{array}$ & $\begin{array}{l}\text { FWL } \\
(\mathbf{g})\end{array}$ & $\begin{array}{l}\text { DWL } \\
(\mathbf{g})\end{array}$ & $\begin{array}{l}\text { LFB } \\
(\mathbf{c m})\end{array}$ & $\begin{array}{l}\text { LPL } \\
(\mathbf{c m})\end{array}$ \\
\hline Control & $32.79 \mathrm{a}^{\&}$ & $5.39 \mathrm{a}$ & $5.08 \mathrm{a}$ & $56.35 \mathrm{a}$ & $16.35 \mathrm{a}$ & $11.51 \mathrm{a}$ & $11.99 \mathrm{ab}$ \\
Estimulante plus $\AA$ & $30.72 \mathrm{a}$ & $5.45 \mathrm{a}$ & $5.26 \mathrm{a}$ & $54.03 \mathrm{a}$ & $15.60 \mathrm{a}$ & $11.09 \mathrm{a}$ & $10.87 \mathrm{~b}$ \\
AeroBiot $\AA$ & $35.98 \mathrm{a}$ & $5.82 \mathrm{a}$ & $5.67 \mathrm{a}$ & $58.38 \mathrm{a}$ & $16.30 \mathrm{a}$ & $12.33 \mathrm{a}$ & $12.68 \mathrm{a}$ \\
Basfoliar Activ ${ }^{8}$ & $35.20 \mathrm{a}$ & $5.39 \mathrm{a}$ & $5.35 \mathrm{a}$ & $55.93 \mathrm{a}$ & $16.05 \mathrm{a}$ & $11.47 \mathrm{a}$ & $12.05 \mathrm{ab}$ \\
Basfoliar PS $\AA$ & $32.69 \mathrm{a}$ & $5.56 \mathrm{a}$ & $5.26 \mathrm{a}$ & $56.90 \mathrm{a}$ & $16.18 \mathrm{a}$ & $11.61 \mathrm{a}$ & $10.63 \mathrm{~b}$ \\
HPLS & $34.33 \mathrm{a}$ & $5.30 \mathrm{a}$ & $5.12 \mathrm{a}$ & $50.53 \mathrm{a}$ & $14.65 \mathrm{a}$ & $10.63 \mathrm{a}$ & $11.45 \mathrm{ab}$ \\
\hline MSD & 4.43 & 0.6 & 0.62 & 22.81 & 6.55 & 1.22 & 1.52 \\
ANOVA $(P=.05)$ & 0.1983 & 0.5555 & 0.4323 & 0.9839 & 0.9963 & 0.1460 & 0.0904 \\
Coefficient of & 8.87 & 7.42 & 7.94 & 27.74 & 27.75 & 7.2 & 8.84
\end{tabular}

variation (\%)

$\&=$ average followed by the same letter in the columns are statistically equal $L S D$ Fisher ( $L S D \leq .05)$,

$D E F=$ equatorial diameter of fruit, $L L=$ length of leaflet, $L W=$ leaflet width, $F W L=$ fresh weight of leaf,

$D W L=$ dry weight of leaves, $L R F=$ length of fruit bunch, $L P L=$ leaf petiole length, $M S D=$ minimum significant difference
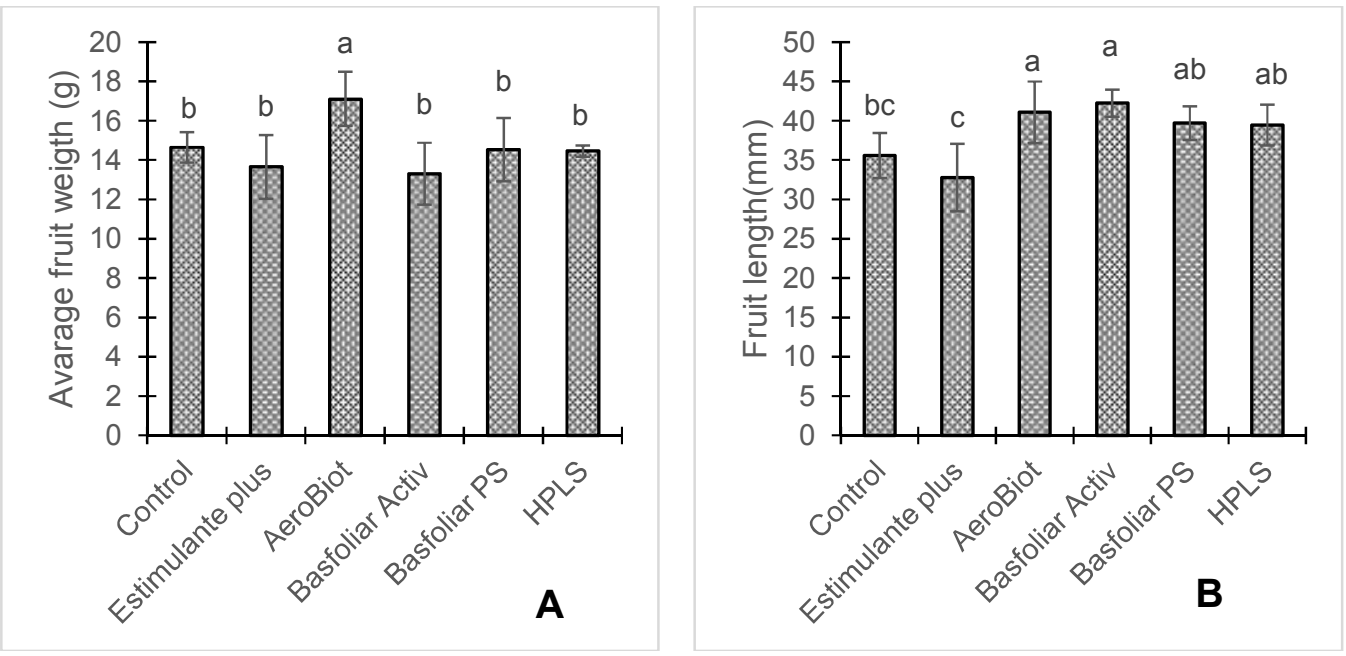

Fig. 2. Average fruit weight $(A)$ and fruit length $(B)$ of strawberry treated with different supplementary foliar products. ANOVA $P=.05$, LSD Fisher mean test $(L S D \leq .05)$. Vertical bars correspond to standard deviation 


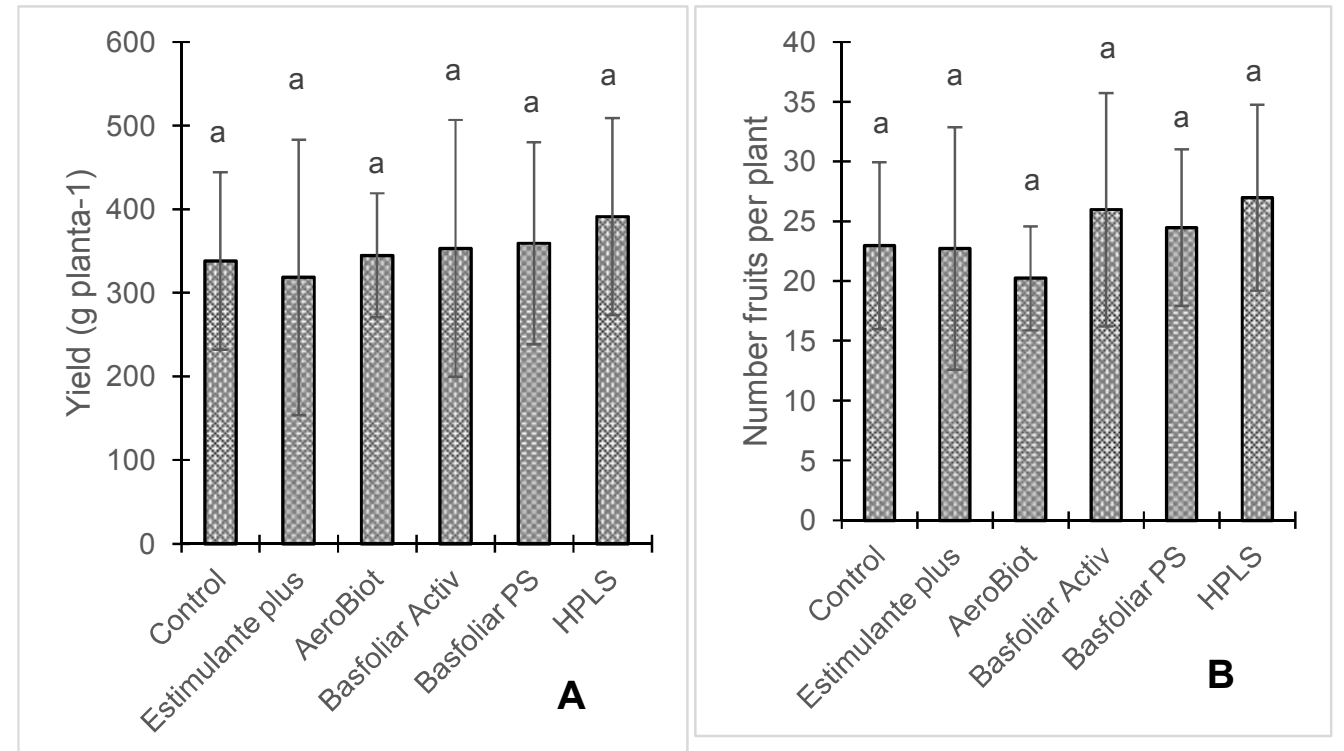

Fig. 3. Yield in g plant $^{-1}(A)$ and number of fruits per plant $(B)$ in strawberry plants treated with different supplementary foliar products. ANOVA $P=.05$, LSD Fisher mean test $(L S D \leq .05)$. Vertical bars correspond to standard deviation
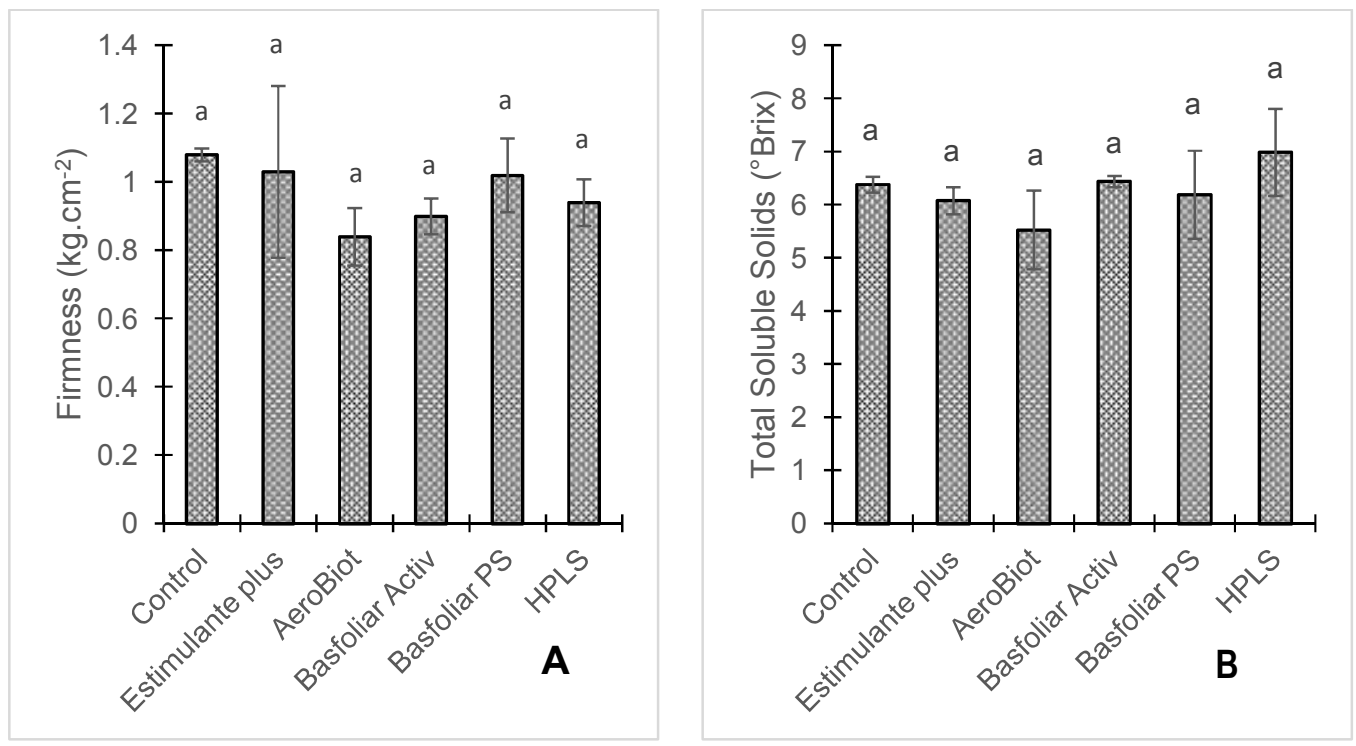

Fig. 4. Firmness (A) and total soluble solids (B) in strawberry plants treated with different supplementary foliar products. ANOVA $P=.05$, LSD Fisher mean test $(L S D \leq .05)$. Vertical bars correspond to standard deviation

\section{CONCLUSION}

The agronomic performance of the strawberry crop in a vertical system was similar between supplementary foliar applications of products with macro and microelements, amino acids and protein hydrolysates. Foliar derived from worm leachate such as AeroBiot $($ improve the average weight of strawberry fruit. The agronomic variables and fruit quality is not affected by foliar applications. Therefore, it is inferred that the similar response between treatments is the result of an appropriate nutrient supply through the nutrient solution. 


\section{DISCLAIMER}

The products used for this research are commonly and predominantly use products in our area of research and country. There is absolutely no conflict of interest between the authors and producers of the products because we do not intend to use these products as an avenue for any litigation but for the advancement of knowledge. Also, the research was not funded by the producing company rather it was funded by personal efforts of the authors.

\section{ACKNOWLEDGEMENTS}

Thanks the plant breeding department of the Antonio Narro Autonomous Agrarian University for facilitating the greenhouse and the research project that could be carried out.

\section{COMPETING INTERESTS}

Authors have declared that no competing interests exist.

\section{REFERENCES}

1. SIAP. Agri-food and fisheries information service. Accessed 2019.

Available:https://nube.siap.gob.mx/cierreag ricola/

2. PAN. National Agricultural Planning. Secretariat of Agriculture, Livestock, Rural Development, Fisheries and Food; 2017. Accessed 2019.

Available:https://www.gob.mx/cms/uploads /attachment/file/257075/Potencial-

Fresa.pdf

3. Wasaya A, Muhammad S, Mubshar $\mathrm{H}$, Muhammad A, Ahsan A, Waseem H, ljaz A. Foliar application of zinc and boron improved the productivity and net returns of maize grown under rainfed condition of Pothwar plateau. J. of Soil Sci. and Plant Nutr. 2017;17(1):33-45.

Available:http://dx.doi.org/10.4067/S071895162017005000003

4. Nusimovich A, Gomis P, Avila L, Escaich J. Effects of foliar absorption of amino acids obtained by enzymatic and nutrient pathways in a tomato crop (Lycopersicum esculentum Mill. Var. Quattor). Agricola Vegetal. 1989;85:47-48.

5. Villegas TOG, Rodríguez MMN, TrejoTLI, Alcántar GG. Potential of honey in the nutrition of tomato seedlings. Terra Latinoamericana. 2001;19:97-102.
Available:https://www.redalyc.org/articulo.o a?id=57319112

6. Rodríguez MMN, Baca CG, García CJL, Urrieta VJA. Thinning of fruits and sprinkles of calcium and honey on the quality of rib tomato. Rev. Fitotec. Mex. 2015;38(2):197-204.

Available:http://www.scielo.org.mx/pdf/rfm/ v38n2/v38n2a10.pdf

7. Fernández $\mathrm{V}$, Brown $\mathrm{PH}$. From plant Surface to plant metabolism: The uncertain fate of foliar- applied nutrients. Plant Sci. 2013;31(4):289-295.

DOI: $10.3389 /$ fpls.2013.00289

8. Fernández $V$, Sotiropulus $T$, Brown $P$. Foliar fertilization scientific principles and field practice. International Association of the Fertilizer Industry. Paris, Francia. 2015;22-30.

Available:https://www.researchgate.net/pu blication/283908842_Fertilizacion_Foliar_ Principios_Cientificos_y_Practicas_de_Ca mpo

9. Li C, Wang P, Menziez NW, Lombi E, Kopittke PM. Effects of changes in leaf properties mediated by metyl jasmonate (MeJA) on foliar absorption of $\mathrm{Zn}, \mathrm{Mn}$ and Fe. Annals of Botany. 2017;120(3):405415.

DOI: 10.1093/aob/mcx063

10. Sadak SHM, Abdelahim MT, Schmidalter $U$. Effect of foliar aplication of aminoadis on plant yield and some physiological parameters in faba bean plants orrogated with seawater. Acta Biológica Colombiana. 2015;20(1)141-152.

Available:http://dx.doi.org/10.15446/abc.v2 On1.42865

11. Viasus QG, Álvarez $\mathrm{HJ}$, Alvarado SO. Effect of the application of gibberellins and 6-benzylaminopurine on strawberry production and quality (Fragaria $x$ ananasa Duch.). Bioagro. 2013;25(3):195-200.

Available:http://ve.scielo.org/pdf/ba/v25n3/ art07.pdf

12. Franco LJA. Use of protein hydrolysates in horticulture. Horticultura. 1989;52:60-64.

Available:https://www.mapa.gob.es/ministe rio/pags/biblioteca/revistas/pdf_Hort/Hort_ 1989_52_60_64.pdf

13. Trinidad SA, Aguilar MD. Foliar fertilization, an important support in crops. Terra latinoamericana. 1999;17(3):247255.

Available:https://www.redalyc.org/pdf/573/ 57317309.pdf 
14. Carrillo MO, Rodríguez AJ, Cano MR, López JA. Foliar application of urea and sucrose and its effect on the conditioning of nursery plants and strawberry production (Fragaria $x$ ananasa Duch.) CP 993A. Agrociencia 2005;39:195-204.

Available:https://www.redalyc.org/articulo.o $\mathrm{a}$ ?id $=30239207$

15. Palencia $P$, Martínez $F$, Burducea $M$, Oliveira JA, Giralde I. Effects of selenium enrichment on spad, fruit quality and strawberry growth parameters in a soilless cultivation system. Rev. Bras. de Frutic. 2016;38(1):202-212.

Available:http://dx.doi.org/10.1590/01002945-294/14

16. Vaca TJM. Foliar application of calcium in strawberry cultivation (Fragaria $s p$.) obtained from chicken eggshell (Gallus gallus). Tesis de Licenciatura. Universidad Técnica de Ambato. Facultad de Ciencias Agropecuerias. Ambato, Ecuador; 2019.

Available:https://repositorio.uta.edu.ec/bitst ream/123456789/29517/1/Tesis-

231\%20\%20Ingenier\%C3\%ADa\%20Agron

\%C3\%B3mica\%20-CD\%20632.pdf

17. Ibadango RF. Cazco LC. Efficiency and profitability of the vertical hydroponic system compared to the conventional one in the production of three varieties of strawberry (Fragaria Vesca L.) at the experimental farm Yuyucocha, Imbabura. IX Congreso Latinoamericano de Agronomía. Taguragua, Ecuador; 2017. Available:https://cidecuador.org/wpcontent/uploads/congresos/2017/ixcongreso-latinoamericano-deagronomia/diapo/eficiencia $\% 20 \mathrm{y} \% 20$ renta bilidad $\% 20$ del $\% 20$ sistema $\% 20$ hidroponico \%20vertical\%20frente\%20al\%20convencio nal $\% 20$ en $\% 20$ la $\% 20$ produccion $\% 20$ de $\% 2$ 03\%20variedades $\% 20$ de $\% 20$ fresa_felix $\%$ 20ibadango.pdf

18. Hernández PBV. Strawberry yield and quality evaluation in two hydroponic systems. Tesis de Licenciatura. Universidad Autónoma del Estado de México. Facultad de Ciencias Agrícolas. Toluca, México; 2017.

Available:http://ri.uaemex.mx/handle/20.50 $0.11799 / 67929$

19. Castañeda SMA, Gómez GG, Tapla CE, Nuñez MO, Barajas PJS, Rujano SML. Effect of Azospirillum brasilense and chemical fertilization on the growth, development and quality of strawberry fruit (fragaria $\mathrm{x}$ ananassa Duch). Interciencia. 2013;38(10)737-744.

Available:https://www.redalyc.org/pdf/339/ 33929482008.pdf

20. Boudet AA, Fabre B, Meriño $Y$. Effect of the application of organic fertilizers on the agro-productive response of the bean crop. Revista Centro Agrícola. 2015;42(2):11-16.

Available:http://cagricola.uclv.edu.cu/desc argas/pdf/V42-Numero_2/cag02215.pdf

21. Rodríguez FPA. Impact of worm humus leachate on the growth and productivity of the bean crop (Vigna unguiculata Walt). Ciencia en su PC. 2017;2:44-58.

Available:https://www.redalyc.org/pdf/1813 /181351615003.pdf

22. Martínez SMM, Ruiz HJ. Effect of the application of earthworm leachate and humic acids in the production of bell pepper. Revista de Ciencias Naturales y Agropecuarias. 2018;5(1):19-24.

Available:http://www.ecorfan.org/bolivia/re searchjournals/Ciencias_Naturales_y_Agr opecuarias/vol5num15/Revista_de_Cienci as_Naturales_y_Agropecuarias_V $\overline{5} \_$N15 4.pdf

23. Borges JA, Barrios $M$, Chávez $A$, Avendaño R. Effect of foliar fertilization with liquid worm humus during the revival of morrea (Morus alba L.). Bioagro. 2014;26(3):159-164.

Available:http://ve.scielo.org/pdf/ba/v26n3/ art04.pdf

24. Du JP. Plant bioestimlant: Definition, concepts, main categories and regulation. Scientia Horticulturae. 2015;196:3-14.

Available:https://core.ac.uk/download/pdf/8 2621513.pdf

25. Pastor SJN, Martín CL, Guinesta FA, Costa TJ. Influence of the application of synthetic amino acids in the development of tomato plants grown under salinity conditions. Horticultura. 2013;60:261-267. Available:http://www.sech.info/ACTAS/Act a\%20n\%C2\%BA\%2060.\%20XIII\%20Cong reso $\% 20$ Nacional $\% 20$ de $\% 20$ Ciencias $\% 20$ Hort\%C3\%ADcolas/Horticultura/Influencia \%20de\%20la\%20aplicaci\%C3\%B3n\%20d e\%20amino\%C3\%A1cidos\%20de\%20s\% C3\%ADntesis\%20en\%20el\%20desarrollo $\% 20$ de $\% 20$ plantas $\% 20$ de $\% 20$ tomate $\% 20$ c ultivadas $\% 20$ bajo $\% 20$ condiciones $\% 20$ de \%20salinidad.pdf

26. Colla G, Rouphael $Y$, Canaguier R, Svecova E, Cardarelli M. 
Biostimulantaction of a plant-derived protein hydrolysate produced through enzymatichydrolysis. Front. Plant Sci. 2014:5:1-6.

Available:https://doi.org/10.3389/fpls.2014. 00448

27. Kato $\mathrm{Y}$, Nakamura $\mathrm{K}$, Hashimoto $\mathrm{T}$. Recovery of proteins in high performance ion exchange chromatography. Journal of Separation Science. 1985;8(3):154155.

Available:https://doi.org/10.1002/jhrc.1240 080314

28. Calvo P, Nelson L, Kloepper JW. Agricultural uses of plant biostimulants. Plant Soil. 2014;383: 3-4.

Available:https://link.springer.com/article/1 $0.1007 / \mathrm{s} 11104-014-2131-8$

(c) 2021 Cortez et al.; This is an Open Access article distributed under the terms of the Creative Commons Attribution License (http://creativecommons.org/licenses/by/4.0), which permits unrestricted use, distribution, and reproduction in any medium, provided the original work is properly cited.

Peer-review history:

The peer review history for this paper can be accessed here: http://www.sdiarticle4.com/review-history/66517 